\title{
Pilkada Amidst a Pandemic: The Role of The Electronic Word of Mouth in Political Brand and Voting Intention
}

\author{
Linda Fitriani ${ }^{1}$, Jono M Munandar ${ }^{2}$, Ujang Sumarwan ${ }^{3}$ \\ ${ }^{1}$ Management Science, IPB University, Indonesia (email: lindafitrianilinda@apps.ipb.ac.id) \\ ${ }^{2}$ Department of Management, IPB University, Indonesia (email: jonomu@apps.ipb.ac.id) \\ ${ }^{3}$ Graduate Program in Management and Business, IPB University, Indonesia \\ (email: usumarwan@gmail.com)
}

\begin{abstract}
The Regional Head Election campaign frequently uses electronic Word of Mouth (eWOM) communication because of social media's growth and the Covid-19 pandemic that took place during the election year. In commercial brands, eWOM impact has influence brand equity and purchase decisions. However, in political brands, this has not been proven. Therefore, by using the regional head candidate of Purbalingga Regency as a political brand, this study examines the effect of eWOM on developing candidate brand equity and relates it to voting intention. Brand equity using a brand pyramid model with brand equity forming variables consisting of a candidate brand awareness, a candidate brand performance-imagery, a candidate brand judgment-feelings, and a candidate brand resonance. The study involved 260 respondents who are people of Purbalingga Regency who may vote and use social media. The sampling method used was purposive sampling by conducting direct interviews with respondents. Data were analyzed using Structural Equation Model Partial Least Square (SEM PLS) analysis. The results showed that electronic Word of Mouth has a positive and significant effect on brand equity development variables. Developing brand equity affects the voting intention on candidate brand awareness and candidate brand resonance. The Result of this study found electronic Word of Mouth to have no direct influence on voting intention.
\end{abstract}

Keywords:

electronic Word of Mouth; candidate brand building; voting intention

\section{Introduction}

The Simultaneous Regional Head Elections (Pilkada Serentak) in 2020 have different challenges from the previous regional elections because the Covid-19 pandemic spread appeared, including in Indonesia. This condition requires all parties involved in the Pilkada to comply with health protocols to minimize the risk of the spread of the Covid-19 virus. The General Election Commission/ Komisi Pemilihan Umum (KPU) of the Republic of Indonesia, therefore, stipulated a ban on the traditional (conventional) campaign period in the 2020 simultaneous regional elections. KPU released a statement about KPU Regulation
(PKPU) Number 13 of 2020 concerning the Second Amendment to PKPU Number 6 of 2020 concerning the Implementation of Simultaneous Continuous Pilkada In in the Non-Natural Disaster Condition of Covid-19, the KPU prohibits political parties, candidate pairs, campaign teams, and other parties from carrying out campaign activities as if enduring normal conditions. Among them are general meetings, art performances, harvest festivals, music concerts, leisurely walks, relaxing bicycles, competitions, bazaars, and blood donations to commemorate political parties' anniversaries (KPU, 2020b)(KPU, $2020 b)$. This regulation forces every candidate 
to switch from traditional campaigns to digital campaigns, where social media is the alternative media suggested by the KPU to candidates and campaign teams (KPU, 2020a) (KPU, 2020a).

Social media is a medium that Indonesians widely use to satisfy their information needs during the global Covid-19 pandemic (Rohmah, 2020). (Rohmah, 2020). In social media, participants engage in communication in networks where individuals rarely know each other but maintain relationships through this network (King et al., 2014). (King et al., 2014). Social media has resilience in influencing public opinion and getting fast voice support because social media speeds up delivering messages (Susanto, 2017). However, PKPU Number 4 of 2017, the General Election Commission and PKPU number 11 of 2020 concerning PKPU Number 4 of 2017 concerning the Election Campaign, restrict the use of social media as a campaign medium. This regulation regulates campaign advertisements on social media, which only may air at times scheduled by the KPU. The KPU also limits official accounts owned by the campaign team to a maximum of 20 (KPU, 2020b).(KPU, 2020b).

Even though there is a limitation on campaign advertising, social media still can be the most effective means of socialization, namely Word of Mouth (Tinarbuko, 2019). (Tinarbuko, 2019). Word of Mouth communication on this digital platform is known as electronic Word of Mouth (eWOM). According to Cheung \& Thadani (2012), electronic Word of Mouth is communication between consumers via the internet or information technology. The ease of using the internet and social networks has proven eWOM to be an essential marketing tool and a central platform for interactive marketing communications (Alhidari et al., 2015). The effect of eWOM is more remarkable than traditional word of mouth because of its convenience, scope, source, and interaction speed. By using electronic media by word of mouth on social media Snapchat, Twitter, and Facebook, Barnie Sanders' campaign attracted millennial voters in comparison (Grothaus, 2016). Donald Trump is also superior to Hillary Clinton, who spends twice as much on marketing communications by relying on the power of electronic Word of Mouth on social media (Pramuk, 2016). Business actors and candidates use eWOM as a political brand.

In political campaigns, candidates have the same role as product brands and have become valuable political brands to facilitate voter choice among candidates in the political arena (Needham \& Smith, 2015). This political arena includes all types of elections, national and regional elections. Using political campaigns helps regional head candidates build and create strong candidates because a strong candidate brand will increase the offer's value in voters' eyes (Cwalina \& Falkowski, 2015). In commercial brands, several studies support this idea. Sijoria et al. (2018) have shown that eWOM uses a Systematic Literature Review (SLR) involving 93 articles published over the past 15 years and found that eWOM has a significant effect on consumer-based brand equity (CBBE). Based on quantitative research from Augusto \& Torres (2018), it also proves that eWOM impacts consumer-based equity in service products. In other studies, electronic Word of Mouth (eWOM) affects several variables that form consumer-based brand equity, namely brand awareness, brand association, brand image, and brand resonance (Abubakar et al., 2016; Cheng et al., 2019; Sharifpour, 2018). However, these studies only focused on commercial brands and showed no relationship between eWOM and purchase intention.

Meanwhile, in the political context, the influence of eWOM was studied by Hultman et al. (2019). Hultman's research involved 305 respondents in the UK and used SEM analysis. His research found that EWOM affects one of the brand-building variables, namely candidate 
image and relationship equity. Iyer et al. (2017) also examined the impact of different WOM / eWOM political messages (superficial vs. deep) conveyed through various communication channels on evaluating voter messages, beliefs, attitudes toward messages and communication, message involvement, and voting intention.

Research exists on the importance of eWOM in regulating brand equity. However, the role of eWOM in influencing variables forming brand equity is still limited to a few and always focuses on commercial brands. In a political context that uses marketing theory, research on eWOM and brand equity is still very limited. Knowledge of eWOM communication in political brands will be beneficial for theoretical and practical developments. Theoretically, this will be a new knowledge that can enrich the political marketing science. Whereas practically, knowledge about eWOM communication against political brands will be beneficial for candidates to find effective and efficient political marketing communications, especially in the conditions of the Covid-19 epidemic. Therefore, the authors are interested in examining the role of electronic Word of Mouth (eWOM) in building a candidate's political brand equity, which will also influence the voting intention. Using the brand pyramid model from marketing theory, the researcher examines the effect of EWOM on all candidate brand building variables (candidate brand awareness, candidate brand performanceimagery, candidate brand judgement-feelings, and candidate brand resonance) and relates them to voting intention. The brand pyramid provides a comprehensive and cohesive understanding of building brand equity in the marketplace (Keller, 2020)

The research will take a case study of the Purbalingga Regency area, which conducts the Simultaneous Regional Head Elections (Pilkada Serentak) in 2020. Purbalingga Regency is a district with a relatively low voter turnout and has a downward trend in implementing the previous Pilkada. In the 2005 Pilkada, the public participation rate reached 72 percent. However, in the 2010 regional elections, this figure had decreased to 66 percent. Meanwhile, in the 2015 regional elections, the public participation rate fell to 60 percent (KPUPurbalingga, 2015). The low level of public participation, which requires a new campaign tool, can attract voters in Purbalingga Regency. Therefore, research on the eWOM area will summarize the effectiveness of eWOM as an alternative campaign tool that candidates can use to build brands and influence people's voting intention.

\section{Literature Review}

\section{Social Media and Electronic Word of Mouth}

Besides serving the needs of entertainment and social surveillance (Boyd \& Ellison, 2007), social media platforms also provide a space where individuals share political opinions and information (Pew, 2015). This activity of sharing opinions and information has led to Word of Mouth communication on social media, known as electronic Word of Mouth (eWOM). Hennig-Thurau et al. (2004;39) define eWOM as positive or negative statements made by potential, actual, or former customers regarding a product or company, available to many people and institutions via the internet. Word of mouth on this digital platform is not only limited to the customer's statement but also includes posts from retailers or other published sources, which potential, current or previous customers share or repost about a product or brand (Hu, 2014). In a political campaign, eWOM is a political message received and conveyed back in social networks.

Kudeshia \& Kumar (2017), in their research, use the term social eWOM, which indicates any information related to the brand/product and exchanges among social networking site users. The dissemination of information related to the brand of a local election's candidates is more prevalent on 
social networking sites than on other internet networking sites.

\section{The Candidate Brand Building Using the Brand Pyramid}

The brand pyramid provides a comprehensive and cohesive understanding of building brand equity in the marketplace. The model considers what consumers think, feel, and do and the extent to which they connect or "resonate" with a brand (Keller, 2020). This model consists of six brand building blocks that make up brand equity. The building blocks for a brand consist of brand salience, brand performance, brand imagery, brand judgment, brand feeling, and brand resonance (Keller, 2020). Brand salience measures brand awareness and how easily / often the brand appears in various situations or circumstances. Brand performance is the ability of a brand to meet consumers' functional needs. Brand imagery shows the brand's ability to meet the psychological or social needs of customers. Brand judgment is the customer's opinion and evaluation regarding the brand. Brand feeling is a customer's affective and emotional response to a brand. Brand resonance describes customers' relationships with a brand and how much they feel they are "in tune" with it. Building a brand using these brand-building blocks that could be assembled into a pyramid, as shown in Figure 1.

The role of social media and its environment with brands is receiving more attention because the platform provides marketers with a space to be more interactive. Social media provides services for marketers to serve and provide consumer response and conversation on their platform (Saridakis et al., 2016; Schweidel \& Moe, 2014). Social media also provides an opportunity for brands to better understand their customers (Felix et al., 2017). Therefore, social media is becoming a marketing tool increasingly used in various fields, including political campaigns. Social media has marketing tools consisting of interaction, entertainment, trendy, customization, and word of mouth (Kim \& Ko, 2012).

Word of Mouth is much more effective than other marketing campaigns. Even eWOM affects consumer preferences and purchasing decisions (Chu \& Kim, 2011). EWOM has led to many brands. EWOM on social media has encouraged consumers to share information about their friends and acquaintances on social media (Godey et al., 2016). One brand that utilizes this social media is the brand of political candidates.

\section{Figure 1.}

\section{Brand Pyramid}
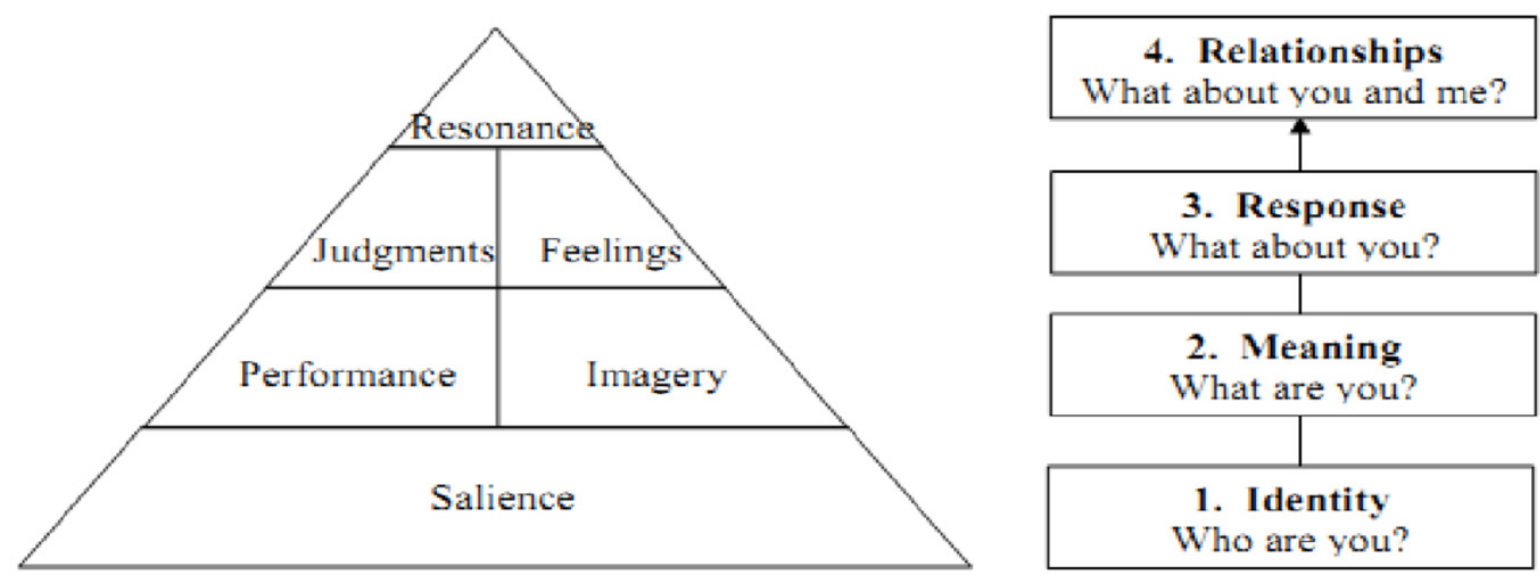

Source: Keller (2020) 
Ahmed et al. (2017) stated that political brand equity depends on how brands are communicated to voters at the voter level through social interactions. In their research, Augusto \& Torres (2018) also proved that eWOM significantly affects brand identification and consumer-based brand equity. In line with the former (Cheng et al., 2019), that information seeking and social interactivity are antecedents of customer brand engagement that will affect brand resonance. Although the literature on the influence of eWOM in voter decision making is still minimal, marketers still consider it one of the essential elements in political marketing, especially for creating a younger generation. Saboo et al. (2016) stated that social media positively influences human brands' power. EWOM on social media is also the most influential element in building and enhancing stronger relationships between brands and consumers (Mooradian \& Swan, 2006).

Given that brand perception is closely related to the brand building pyramid, the eWOM significantly influences the brand development variable represented by the brand resonance model.

H1: eWOM has a significant effect on candidate brand awareness.

$\mathrm{H} 2$ : eWOM has a significant effect on candidate brand performance-imagery.

H3: eWOM has a significant effect on candidate brand judgment-feeling

H4: eWOM has a significant effect on candidate brand resonance.

\section{Voting Intention}

Voting intention is a significant predictor of voting behavior and an indicator for current or short-term political preferences (Dewenter et al., 2019). The voting intention also refers to a person's desire to elect a particular candidate or party (Rachmat, 2014). According to Parker (2012), the candidate's brand equity greatly influences the voting intention. Sharifpour et al. (2016) also stated that eWOM affects brand awareness and intention to choose. Abubakar et al. (2016) also showed a relationship between eWOM, brand image, and intention to choose. Brand awareness and brand image are among the variables in brand development, so other brand development variables positively influence intention to choose.

H5: Candidate brand awareness has a positive effect on voting intention

H6: Candidate brand performance-imagery have a positive effect on voting intention H7: Candidate brand judgment-feeling have a positive effect on voting intention

H8: Candidate brand resonance has a positive effect on voting intention

Meanwhile, the relationship between message engagement and intentions to behave is well established, especially in political marketing (Schofield \& Reeves, 2015). Dabula (2017) shows the influence of social media on voting intention. Therefore, the authors also hypothesize the direct effect of eWOM on the intention to choose.

H9: Electronic Word of Mouth has a significant effect on voting intention.

\section{Methods}

This study uses a quantitative method with a survey design. According to Creswell (2016), quantitative methods can examine the relationship between variables. Primary data collecting by survey methods and interviews using a questionnaire with structured questions. The questionnaire comprises indicators that represent the variables to be studied. The variable electronic Word of Mouth uses indicators adapted from Kudeshia \& Kumar (2017), candidate brand building adapts from the brand pyramid introduced by Keller (2013), and the voting Intention to adopt from (Ajzen, 2013). The validity and reliability demonstrated that all research instruments in the questionnaire were declared valid and reliable.

The sampling method used was nonprobability sampling with the purposive 
sampling technique. The sample size was 260 respondents who are members of the Purbalingga Regency community who may vote and use social media. The survey was conducted a week before the election by trained enumerators. The data obtained will be analyzed using the Structural Equation Model with SMART PLS 3.2 software.

Structural Equation Model (SEM) is a statistical technique for testing and estimating causal relationships using a combination of statistical data and qualitative causal assumptions (Abdillah \& Jogiyanto, 2015). The PLS-SEM method is desirable to many researchers because it allows them to estimate complex models with many constructs, indicator variables, and structural paths without imposing distribution assumptions on the data (Hair et al., 2019). This equation describes all the relationships between variables that build the model in an analysis. SEM is used to determine a quantity that states how strong the relationship of a variable is to other variables without questioning whether a particular variable depends on other variables. The software used is SMART PLS 3.2.

SEM analysis uses measurements carried out on two variables, namely the latent variable and the manifest variable. Latent variables are variables that cannot be measured directly but use indicators or manifest. Meanwhile, manifest variables are measurable indicators (Ghozali, 2008). Latent variables are divided into 1) exogenous, a latent variable whose value is determined by other variables outside the model, and 2). Endogenous is a latent variable whose value is defined by other variables in the model. This study used one exogenous variable and five endogenous variables. The exogenous variables are the electronic Word of Mouth, while the endogenous variables are candidate brand awareness, candidate brand performance-imagery, candidate brand judgment-feelings, candidate brand resonance, and the voting intention. The research variables and hypotheses in them are shown in the conceptual research model, shown in Figure 2.

The stages of data analysis using the SEMPLS method (Ghozali, 2008) are:

1. Designing the structural model (inner model) and measurement model (outer model).

The inner model or structural model describes the relationship between latent variables based on substantive theory. The structural model of the relationship between latent variables is based on formulating the problem or research hypothesis. Meanwhile, the outer model or measurement model defines how each indicator block relates to its latent variable. The measurement model's design determines each latent variable's indicator properties, whether reflective or formative, based on the operational definition of the variable.

\section{Construct a path diagram}

After designing the structural model (inner model) and measurement model (outer model), it is then expressed in a path diagram. Figure 2 shows the path diagram in this study.

3. Evaluation of outer model and inner model.

a. Measurement Model (Outer Model)

1) Convergent validity, the correlation between the reflective indicator score and the latent variable score. For this, the loading factor of 0.5 to 0.6 is considered sufficient (Abdillah and Hartono, 2016). The number of indicators per construct is small, ranging from 3 to 7 (seven) indicators.

2) Discriminant validity, comparing the square root of average variance extracted (AVE) value of each construct with the correlation between other constructs in the model, if the AVE root of the construct is greater than the correlation with all other constructs, it is said to have good discriminant validity. 
Figure 2.

\section{Research Conceptual Model}

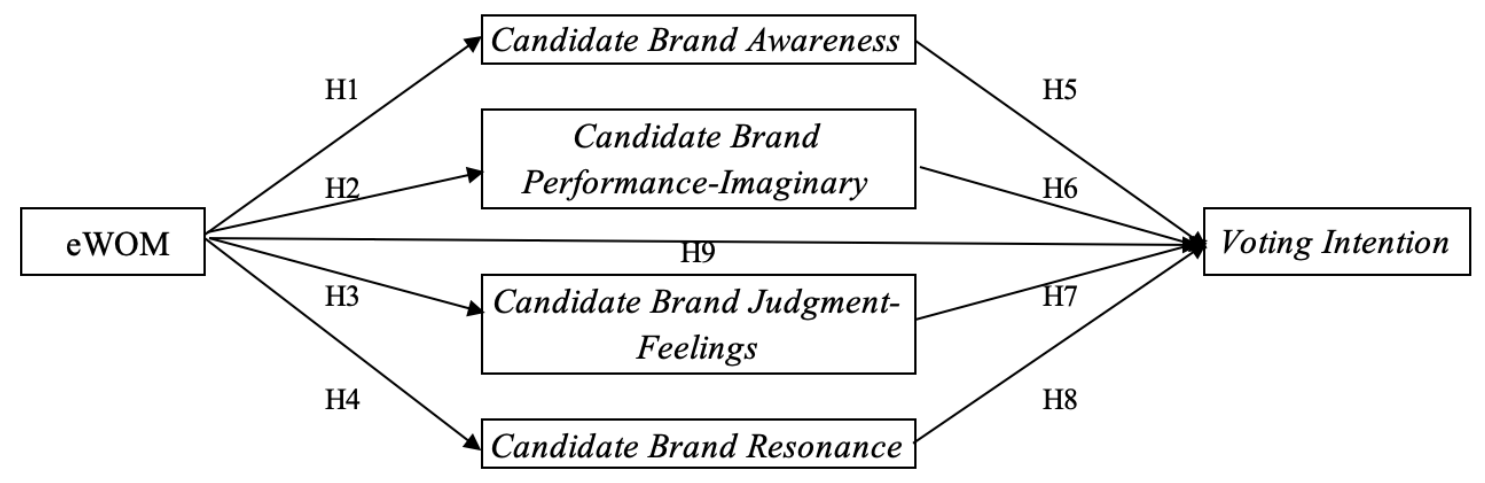

\section{Source: Authors}

The recommended measurement value must be greater than 0.50 .

b. Structural Model (Inner model).

The goodness of Fit Model is measured using R square dependent latent variable with the same interpretation as regression; $Q$ square predictive relevance for structural models measures how well the model and its parameter estimates generate the observed value. The value of $\mathrm{Q} 2>0$ indicates that the model has predictive relevance; conversely, if the value of $\mathrm{Q} 2 \leq 0$ suggests that the model lacks predictive relevance. The quantity of Q2 has a value with a range of $0<\mathrm{Q} 2<1$. Therefore, it is closer to 1 means that the model is getting better. The magnitude of Q2 equals the total coefficient of determination in the path analysis. In this model, the path coefficient value or $\mathrm{t}$-value indicates the level of significance in hypothesis testing. For hypothesis testing at 5 percent alpha and 80 percent power, if the path coefficient value shown by the statistical value ( $t$-statistic) is $\geq 1.96$, then the hypothesis can be stated as supported.

\section{Results}

Structural Equation Model (SEM) is a statistical technique used in determining the measurement model and structural model. Causality relationship ie, when a change occurs in one variable will affect other variables, is the basis of SEM. SEM for researchers has a high degree of flexibility to link theory with data (Ghozali 2008). SEM has become the dominant analytical tool for testing causal relationship models with latent variables (Hair, Jr. 2015). SEM analysis uses measurements made on two variables, namely the latent variable and the manifest variable. PLS analysis was carried out in three stages: analysis of the measurement model (outer model), the inner model (inner model), and hypothesis testing.

\section{Analysis of the Measurement Model (Outer Model)}

This analysis was conducted to see the relationship between latent variables and their indicators. First, to see the convergent validity, the coefficient of each indicator will be seen. Indicators with a loading factor below 0.7 are considered unsuitable and must be removed from the model. However, according to Abdillah \& Hartono (2016), researchers should not delete indicators with an outer loading of $0.5-0.7$, as long as the AVE value and the variable communality are over 0.5. The initial model's convergent validity results show indicators whose coefficient values do not meet the requirements. Therefore, the authors re-specify by eliminating these indicators. Some indicators were removed from the initial 
model, so the remaining 27 indicators meet the standard values.

After testing the convergent validity, the discriminant validity test is carried out to analyze whether the indicator can reflect the latent variable by looking at the cross loading score. The cross loading analysis results in this study follow the criteria, where the correlation value of the cross-landing construct with indicators is more excellent than other construct measures. The measurement was continued by comparing the square root value of the Average Variance Extracted (AVE) of each construct. The model is said to have a good discriminant validity value if the AVE square root value in each construct is greater than the correlation value between constructs and other constructs. Model reliability testing will be carried out by looking at the Composite Reliability (CR) and Cronbach's alpha values. If the value of $C R$ and Cronbach's alpha is greater than 0.7, then the construct is declared reliable. CR, Cronbach's alpha, and AVE values can be seen in Table 1 .

Table 1.

\section{Results of Cronbach's alpha, CR and} AVE testing

\begin{tabular}{llll}
\hline \multicolumn{1}{c}{ Variables } & Cronbach's alpha & CR & AVE \\
\hline EWOM & 0.917 & 0.931 & 0.662 \\
CBA & 0.808 & 0.879 & 0.652 \\
CBPI & 0.848 & 0.908 & 0.767 \\
CBJF & 0.882 & 0.919 & 0.740 \\
CBR & 0.767 & 0.843 & 0.518 \\
VI & 0.671 & 0.802 & 0.507 \\
\hline
\end{tabular}

Source: Processed data (2021)

Based on Table 1, all Cronbach's alpha and Composite Reliability (CR) values are more generous than 0.7 except for voting Intention, which has a Cronbach's alpha value of 0.671 . However, the model is said to have a good reliability value if the Cronbach's alpha and composite reliability values are more significant than 0.7 , but the value of 0.6 is still acceptable (Abdillah \& Hartono, 2016). Meanwhile, Average Variance Extracted (AVE) has a value of more than 0.5 so all variables have met the criteria.

\section{Evaluation of the Structural Model (Inner Model)}

The structural model's evaluation uses $Q$ square predictive relevance to measure how well the model and its parameter estimates generate the observed value. Based on the $\mathrm{Q}$ square calculation, the value is 0.28 , where Q2>0 indicates that the model has predictive relevance. Furthermore, the overall fit index is carried out using the goodness of fit ( $\mathrm{GoF}$ index) based on the formula of Tenenhaus et al. (2005). Based on the calculation results, the resulting goodness of fit value is 0.292 , more significant than 0.26 . Therefore, it can be concluded that the goodness of fit of this research model is included in the large category and high suitability. Testing of the structural model is also done by looking at the R-Square value. The results of calculating the inner model evaluation value can be seen in Figure 3.

The value of $R$ Square for each variable is used in assessing the PLS model. The results of $\mathrm{R}$ Square and the estimation of $\mathrm{R}$ Square can be seen in Table 2.

Table 2.

\section{Results of R Square SEM PLS}

\begin{tabular}{lc}
\hline Variables & R Square \\
\hline Candidate brand awareness & 0.022 \\
Candidate brand performance-imagery & 0.039 \\
Candidate brand judgement-feelings & 0.025 \\
Candidate brand resonance & 0.053 \\
Voting Intention & 0.529 \\
\hline
\end{tabular}

Source: Processed data (2021)

The r-square value is used to measure variation in the independent variable's changes on the dependent variable (Abdillah \& Hartono, 2016). Table 2 shows the R-square value for candidate brand awareness of 0.022 , candidate brand performance-imagery 0.039 , candidate brand judgment-feelings 0.025 , candidate brand resonance 0.053 , and 
Figure 3.

The Result of the Inner Model Evaluation Value Calculation

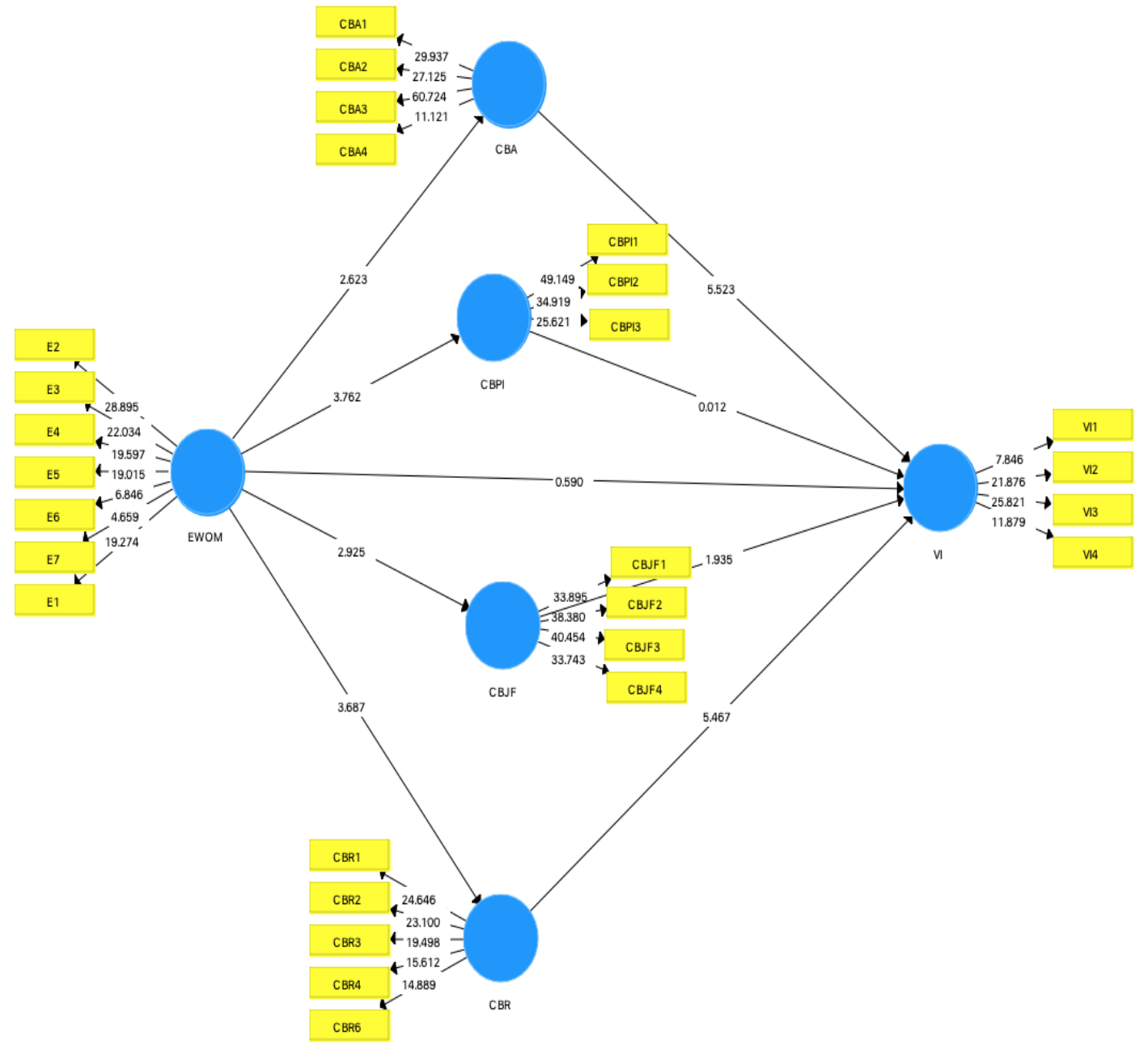

Source: Processed data (2021)

voting intention 0.529 . This shows that the electronic Word of Mouth variable has a positive contribution of 2.2 percent to candidate brand awareness, 3.9 percent to candidate brand performance imagery, 2.5 percent to candidate judgment-feelings, and 5.3 percent to candidate brand resonance, in other words, a positive contribution to development-brand as a whole by 13.9 percent. Meanwhile, the voting intention has an $R$ square value of 0.529 , which can be interpreted that the voting intention variable can be explained moderately by 52.9 percent by the variability of the brand and eWOM development constructs.

\section{Hypothesis test}

The structural model evaluation's essence is hypothesis testing using path coefficient values or $\mathrm{t}$-values to indicate the significance level in hypothesis testing. The consideration used is a significant value of at least $\alpha=0.05$. The hypothesis can be accepted if the path coefficient value is more significant than 0.1 , the $\mathrm{P}$-value is smaller than 0.05 , and the T-statistic value is greater than the $t$-table at the level of $\alpha=0.05$ (1.96). Hypothesis testing is done by resampling using the bootstrapping method to minimize the problem of abnormal research data. The results of the significance test are shown in Table 3. 
Table 3.

Significance Test Results for SEM PLS

\begin{tabular}{lccc}
\hline & $\begin{array}{c}\text { Original } \\
\text { Sample }\end{array}$ & T-Statistic & P-Values \\
\hline EWOM -> CBA & 0.150 & 2.623 & 0.009 \\
EWOM -> CBPI & 0.198 & 3.762 & 0.000 \\
EWOM -> CBJF & 0.158 & 2.925 & 0.004 \\
EWOM -> CBR & 0.231 & 3.687 & 0.000 \\
CBA -> VI & 0.336 & 5.523 & 0.000 \\
CBPI -> VI & 0.001 & 0.012 & 0.991 \\
CBJF -> VI & 0.174 & 1.935 & 0.054 \\
CBR -> VI & 0.335 & 5.467 & 0.000 \\
EWOM -> VI & -0.025 & 0.590 & 0.556 \\
\hline
\end{tabular}

Source: Processed data (2021)

Based on Figure 2 and Table 1 above, the nine hypotheses are proposed, and six hypotheses are accepted. This can be seen from the T-statistic value greater than 1.96, and the P-value is less than 0.05 . The accepted hypotheses include H1 (eWOM influence on candidate brand awareness), $\mathrm{H} 2$ (eWOM influence on candidate brand performanceimagery), H3 (eWOM influence on candidate brand judgment-feelings), H4 (eWOM effect on candidate brand resonance), $\mathrm{H} 5$ (influence of candidate brand awareness on voting intention), and $\mathrm{H} 8$ (candidate brand resonance on voting Intention). The rejected hypothesis has a T-statistic value of less than 1.96 and a P-value of over 0.005 . The rejected hypotheses include $\mathrm{H} 6$ (the influence of candidate brand performance-imagery on voting intention), $\mathrm{H} 7$ (candidate brand judgment-feelings on voting Intention), and H9 (the effect of eWOM on voting intention).

Electronic Word of Mouth is proven to significantly affect all brand development variables where candidate brand resonance has the most significant influence, seen from the value of the parameter coefficient (original sample) of 0.231 . This means that eWOM can increase candidate brand resonance by 23.1 percent, greater than other brand-building variables. The second most significant influence is on the performance-imagery candidate brand by 0.198 , so eWOM can increase the performance-imagery candidate brand by 19.8 percent. EWOM also increased candidate brand judgment-feelings and candidate brand awareness by 15.8 percent and 15 percent.

Meanwhile, not all brand-building variables influence voting intention. Candidate brand awareness and candidate brand resonance have almost the same effect on voting intention. This can be seen from the two's parameter coefficient value, which is not much different. Candidate brand awareness has a parameter coefficient value of 0.336 , which indicates this variable can increase voting intention by 33.6 percent. Meanwhile, candidate brand resonance can increase voting intention by 33.5 percent because it has a parameter coefficient value of 0.335 . Candidate brand performance-imagery and candidate brand judgment-feelings were found to have no significant effect on voting intention. Likewise, ewom does not have a significant effect on voting intention.

Based on the SEM PLS results, it is also seen that the optimal pathway for the electronic Word of Mouth is influencing the intention to choose. EWOM's optimal path is to increase the candidate brand resonance to affect the intention to vote. Besides, EWOM can also influence voting intention by increasing candidate brand awareness.

\section{Discussion}

The results show that electronic Word of Mouth affects all variables in brand development, namely candidate brand resonance, candidate brand performanceimagery, candidate brand judgment-feelings, and candidate brand resonance. This is in line with the political brand equity model (Ahmed et al., 2017), which states that the political socialization process carried out by political parties/candidates will affect brand awareness, brand association, and brand image. The results showed that electronic Word of Mouth, a form of political socialization, also positively affects 
candidate brand awareness. This indicates that candidate socialization through eWOM on social media can improve voters' ability to recognize and remember candidates. This relationship can be caused because voters often read posts or comments from friends on social media, containing necessary information about candidates, making it easier for voters to identify candidates. This directly increases candidate brand awareness. Besides, political socialization through eWOM also affects the association and brand image, reflected in the performanceimagery candidate brand. This is also in line with Abubakar et al. (2016) and Hultman et al. (2019), which proved that eWOM affects brand image. This shows that eWOM affects the formation of associations and the candidate's brand image in voters' minds through social media. (Rutter et al. (2016) also found that interactions on social media can improve brand performance, increase a positive brand image and relationships between customers. The exchange of information in electronic Word of Mouth allows voters on social media to share stories about candidates regarding their performance or their relationship with certain entities. The way voters assess a candidate's performance and relate it to specific entities reflects the performance-imagery candidate brand.

Cheng et al. (2019) stated that eWOM influences brand resonance. Several factors could cause this discovery. One of them is because relationship equity is more substantial when there is a relationship between customers/voters (Hennig-Thurau et al., 2015; Yuan et al., 2016). The relationship's equity shows a candidate brand resonance that describes how much voters feel that they are in harmony with the candidate. This resonance is characterized by the intensity or depth of psychological ties between the customer and the candidate brand and loyalty.

Meanwhile, this study found a relationship between eWOM and brand judgment-feeling, which previous studies had not shown. Based on the information exchanged on social media, voters knowingly or not try to evaluate a candidate's brand by aggregating all information regarding the brand image's performance and association. Besides, interactions on social media platforms can encourage consumers to develop affection for brands (Kim \& Ko, 2012) and create a relationship between electronic Word of Mouth and candidate brand judgment-feelings.

Overall, the results show a positive and significant relationship between eWOM and candidate brand building. The study results illustrate that social media user voters in Purbalingga Regency use eWOM as a source of information to identify and shape candidate brand development in their minds. These results also align with Kim \& Ko (2012), which states that brand engagement on social media and its interaction with audiences positively affect relationship equity. Relationship equity is defined as consumers' willingness and tendency to develop further and maintain their relationships with the brand. Therefore, brands are making more efforts to build this willingness in consumers' minds through marketing activities on various social media platforms (Hennig-Thurau et al., 2015).

The brand pyramid is a brand development model with a high attachment to brand equity if the brand reaches the top of the pyramid, namely brand resonance (Keller, 2013), and influences voting intention (Parker, 2012). This can also be seen in the research results that prove that candidate brand resonance has a significant and positive effect on voting intention. Candidate brand resonance can be seen from the involvement of voters with brands. Highly engaged customers invest holistically in brand interactions (Hollebeek \& Macky, 2019). The involvement of a customer's brand in social media interactions allows online members to learn more about the brand, share information and brand experiences, and show more significant commitment to a brand (Cheng 
et al., 2019). Commitment to the candidate's high psychological attachment brand to the candidate will increase one's voting intention at election time.

Besides candidate brand resonance, other variables influence voting intention. The results showed there was a significant and positive influence of candidate brand awareness on voting intention. In their research, Sharifpour et al., (2016) stated that brand awareness affects commercial brands' purchase intentions. Besides commercial brands, this also applies to political brands. Voters need to know a candidate well to influence their voting intention. Therefore, information about candidates and their programs needs to be well socialized on social media to bring word of mouth and increase candidate brand awareness from voters. Voters who know and know the candidate and the program well will have the incentive to vote for them.

Meanwhile, the performance-imagery candidate brand is known not to influence voting intention. This differs from that found by Van Steenburg \& Guzmán (2019), which states that a candidate's brand image affects voting intention. In this study, the candidate brand image is constructed with the candidate brand performance, explaining the candidate's performance in meeting the voters' expectations. Voters' ignorance of the candidate's unproven performance has made this variable unable to influence their voting intention. Besides the candidate brand performance-imagery, the variable candidate brand judgment-feelings also do not influence voting intention. These findings indicate that voters' evaluations and emotional responses could not influence voting intention. This discovery could be due to the absence of candidate brand judgment-feelings in voters' minds or voters who do not base their voting intention on evaluations related to the candidate's brand and their feelings towards the candidate. The results showed the relationship between brand building variables (using a brand pyramid) and voting intention, which is new in political marketing research. Some findings cannot be compared with previous studies, especially in a political context.

This study also examines the direct relationship between electronic Word of Mouth and voting intention. The study results differed from Iyer et al. (2017), which states that eWOM influences are voting Intention. The eWOM t-statistic has a value of less than 1.96 and a P-value of over 0.05 , so it is stated that eWOM does not significantly affect voting intention. About candidate brands, eWOM must increase brand awareness and brand resonance to influence voting intention because eWOM cannot directly influence voting intention. This finding could be because exchanging information and experiences related to a candidate's brand will not affect the voting intention if it does not raise voter awareness and psychological ties to the candidate's brand.

By looking at the magnitude of influence between variables, it will be seen that the optimal path for eWOM to influence voting intention is to increase candidate brand resonance and candidate brand awareness. This finding confirms that to optimize word of mouth through social media, eWOM must be well created with brand awareness and resonance. EWOM must contain information that encourages voters to become familiar with and psychologically attached to the candidate. With this, eWOM will effectively influence the voting intention.

Rural areas dominate Purbalingga Regency, and not all villages have adequate internet facilities (Pemkab-Purbalingga, 2020). This condition makes candidates socialize more through outdoor media than social media so that eWOM cannot develop optimally. Therefore, EWOM could not influence the voting intention directly

This study provides insight into the impact of electronic Word of Mouth on social media on 
candidate brand building and voting intention. This shows that eWOM can be an effective and efficient political marketing communication channel in building candidate brands and voting intentions. EWOM is useful because, according to research, it can affect all variables of candidate brand development. EWOM is also an efficient political communication tool because it is shared on social media, which only requires an internet connection to access it. Therefore, political candidates or election participants need to pay more attention to winning strategies on social media because electronic Word of Mouth has been shown to influence brand building and voting intention.

Electronic Word of Mouth on social media can be triggered by providing content issued by candidates. The released content should contain information that can help voters get to know the candidate and the program they are carrying. This will help increase candidate brand awareness in the eyes of voters. According to research, candidate brand awareness will increase the intention to vote. Besides, eWOM needs to be managed so the information shared between voters can increase the psychological bond between voters and candidates. This psychological bond will increase the candidate's brand resonance, influencing the intention to vote.

This research is only limited to one political marketing communication tool, namely electronic Word of Mouth found on social media. This study has not disclosed the impact of other political marketing communication tools on brand building and voting intention. Likewise, the political brands used are limited to the political brands of candidates. Future research needs to look at the impact of other political communication tools to evaluate all tools of political communication. This knowledge is beneficial for election participants, both candidates and political parties, to formulate their political marketing strategies.

\section{Conclusion}

This article analyzes electronic Word of Mouth on social media on candidate brand development and voting intention by taking a case study in the 2020 Local Election Purbalingga Regency. Using the Structural Equation Model analysis, the study results show that electronic Word of Mouth affects social media, which is significant and flattering for all candidate brand building variables, namely candidate brand awareness, candidate brand performance-imagery, candidate brand judgment-feelings, and candidate brand resonance. Candidate brand development is also known to affect voting intention on the candidate brand awareness and candidate brand resonance variables. Meanwhile, eWOM has no direct influence on voting intention.

The results show that eWOM can be a political marketing communication channel in society. Political candidates or election participants need to pay more attention to winning strategies on social media because electronic Word of Mouth has been proven to influence candidate brand building and the voting intention for the public. In managing eWOM on social media, political candidates need to provide as much information about candidates and their programs to foster brand awareness among voters. Besides, it is necessary to manage eWOM to foster a psychological bond between voters and candidates so a brand resonance will affect the voting intention.

This study uses all brand development variables with a brand pyramid model rarely used in previous studies, especially political brands. Besides, the study also links brand development variables intending to choose. The high level of suitability of the model indicates that the constructs built in this research model can explain the phenomena. Therefore, future research could use this research model to identify other marketing tools' impact on brand building and choice intention. Apart from candidates as political brands, the subsequent study could use 
other political brands such as political parties, legislative candidates, and party figures.

\section{References}

Abdillah, W., \& Hartono, J. (2016). Partial Least Square (PLS) Alternatif Structural Equation Modeling (SEM) dalam Penelitian Bisnis. Penerbit Andi.

Abdillah, W., \& Jogiyanto, H. (2015). Partial Least Square (PLS) Alternatif Structural Equation Modeling (SEM) dalam Penelitian Bisnis. Yogyakarta: Penerbit Andi.

Abubakar, A. M., Ilkan, M., \& Sahin, P. (2016). eWOM, eReferral and gender in the virtual community. Marketing Intelligence and Planning, 34(5), 692-710. https://doi. org/10.1108/MIP-05-2015-0090

Ahmed, M. A., Lodhi, S. A., \& Ahmad, Z. (2017). Political Brand Equity Model: The Integration of Political Brands in Voter Choice. Journal of Political Marketing, 16(2), 147-179. https://doi.org/10.1080/15377857 .2015 .1022629

Ajzen, I. (2013). Theory of Planned Behaviour Questionnaire. Measurement Instrument Database for the Social Science, 2-9. https://doi. org/http://dx.doi.org/10.13072/midss.649

Alhidari, A., Iyer, P., \& Paswan, A. (2015). Personal level antecedents of eWOM and purchase intention, on social networking sites. Journal of Customer Behaviour, 14(2), 107-125. https://doi.org/10.1362/1475392 15x14373846805707

Augusto, M., \& Torres, P. (2018). Effects of brand attitude and eWOM on consumers' willingness to pay in the banking industry: Mediating role of consumerbrand identification and brand equity. Journal of Retailing and Consumer Services, 42(1-10). https://doi.org/10.1016/j. jretconser.2018.01.005

Cheng, Y. Y., Tung, W. F., Yang, M. H., \& Chiang, C. T. (2019). Linking relationship equity to brand resonance in a social networking brand community. Electronic Commerce
Research and Applications. https://doi. org/10.1016/j.elerap.2019.100849

Cheung, C. M. K., \& Thadani, D. R. (2012). The impact of electronic word-of-mouth communication: A literature analysis and integrative model. Decision Support Systems, 54(1), 461-470. https://doi.org/ doi:10.1016/j.dss.2012.06.008

Chu, S. C., \& Kim, Y. (2011). Determinants of consumer engagement in electronic WordOf-Mouth (eWOM) in social networking sites. International Journal of Advertising, 30(1), 47-75. https://doi.org/10.2501/IJA30-1-047-075

Creswell, J. W. (2016). Research Design (Pendekatan Metode Kualitatif, Kuantitatif, dan Campuran). Yogyakarta: Pustaka Pelajar.

Cwalina, W., \& Falkowski, A. (2015). Political Branding: Political Candidates Positioning Based on Inter-Object Associative Affinity Index. Journal of Political Marketing, 14(12), 152-174. https://doi.org/10.1080/15377 857.2014.990842

Dabula, N. (2017). The Influence of Political Marketing Using Social Media on Trust, Loyalty and Voting Intention of the Youth of South Africa. Business \& Social Sciences Journal (BSSJ), 2(1), 63-119. https://doi. org/10.26831/bssj.2016.2.1.62-112

Dewenter, R., Linder, M., \& Thomas, T. (2019). Can media drive the electorate? The impact of media coverage on voting intentions. European Journal of Political Economy. 58, 245-261. https://doi.org/10.1016/j. ejpoleco.2018.12.003

Felix, R., Rauschnabel, P. A., \& Hinsch, C. (2017). Elements of strategic social media marketing: A holistic framework. Journal of Business Research. 70, 118-126. https:// doi.org/10.1016/j.jbusres.2016.05.001

Ghozali, I. (2008). Structural Equation Modelling (Edisi II). Universitas Diponegoro.

Godey, B., Manthiou, A., Pederzoli, D., Rokka, J., Aiello, G., Donvito, R., \& Singh, R. (2016). Social media marketing efforts of 
luxury brands: Influence on brand equity and consumer behavior. Journal of Business Research, 69(12), 5833-5841. https://doi. org/10.1016/j.jbusres.2016.04.181

Grothaus, M. (2016). Inside Bernie Sanders's Social Media Machine. Retrieved from https:// www.fastcompany.com/3058681/insidebernie-sanders-social-media-machine

Hair, J. F., Risher, J. J., Sarstedt, M., \& Ringle, C. M. (2019). When to use and how to report the results of PLS-SEM. European Business Review, 00-00. https://doi.org/10.1108/ EBR-11-2018-0203

Hennig-Thurau, T., Gwinner, K. P., Walsh, G., \& Gremler, D. D. (2004). Electronic word-of-mouth via consumer-opinion platforms: What motivates consumers to articulate themselves on the Internet? Journal of Interactive Marketing, 18(1), 38-52. https://doi.org/10.1002/dir.10073

Hennig-Thurau, T., Wiertz, C., \& Feldhaus, F. (2015). Does Twitter matter? The impact of microblogging word of mouth on consumers' adoption of new movies. Journal of the Academy of Marketing Science, 43(3), 375-394. https://doi.org/10.1007/ s11747-014-0388-3

Hollebeek, L. D., \& Macky, K. (2019). Digital Content Marketing's Role in Fostering Consumer Engagement, Trust, and Value: Framework, Fundamental Propositions, and Implications. Journal of Interactive Marketing, 45, 27-41. https://doi. org/10.1016/j.intmar.2018.07.003

$\mathrm{Hu}$, X. (2014). Who Are Fans of Facebook Fan Pages?An Electronic Word of Mouth Communication Perspective. International Journal of Cyber Society and Education. https://doi.org/10.7903/ijcse.1156

Hultman, M., Ulusoy, S., \& Oghazi, P. (2019). Drivers and outcomes of political candidate image creation: The role of social media marketing. Psychology and Marketing, 1-11. https://doi.org/10.1002/ mar.21271
Iyer, P., Yazdanparast, A., \& Strutton, D. (2017). Examining the effectiveness of WOM/eWOM communications across age-based cohorts: implications for political marketers. Journal of Consumer Marketing, 34(7), 646-663. https://doi.org/ doi.org/10.1108/JCM-11-2015-1605

Keller, K. L. (2013). Strategic Brand Banagement (global edition). UK: Pearson Education.

Keller, K. L. (2020). Leveraging secondary associations to build brand equity: theoretical perspectives and practical applications. International Journal of Advertising, 1-18. https://doi.org/10.1080 /02650487.2019.1710973

Kim, A. J., \& Ko, E. (2012). Do social media marketing activities enhance customer equity? An empirical study of luxury fashion brand. Journal of Business Research, 65(10), 1480-1486. https://doi. org/10.1016/j.jbusres.2011.10.014

King, R. A., Racherla, P., \& Bush, V. D. (2014). What we know and don't know about online word-of-mouth: A review and synthesis of the literature. Journal of Interactive Marketing, 28(3), 167-183. https:// doi.org/10.1016/j.intmar.2014.02.001

KPU-Purbalingga. (2015). Hasil Hitung TPS Kabupaten Purbalingga. Retrieved from https://pilkada2015.kpu.go.id/ purbalinggakab

KPU. (2020a). KPU Dorong Kampanye Pilkada 2020 Optimalkan Media Daring. https://nasional. kompas.com/read/2020/09/24/17351871/ kpu-dorong-kampanye-pilkada-2020optimalkan-media-daring?page $=$ all

KPU. (2020b). Peraturan Komisi Pemilihan Umum $R I$. Retrieved from https://jdih.kpu.go.id/ detailpkpu-6a4d54587041253344253344

Kudeshia, C., \& Kumar, A. (2017). Social eWOM: does it affect the brand attitude and purchase intention of brands? Management Research Review, 40(3), 310330. https://doi.org/10.1108/MRR-072015-0161 
Mooradian, T. A., \& Swan, K. S. (2006). Personality-and-culture: The case of national extraversion and word-ofmouth. Journal of Business Research, 59(6), 778-785. https://doi.org/10.1016/j. jbusres.2006.01.015

Needham, C., \& Smith, G. (2015). Introduction: Political Branding. Journal of Political Marketing, 14(1-2), 1-6. https://doi.org/1 0.1080/15377857.2014.990828

Parker, B. T. (2012). Candidate Brand Equity Valuation: A Comparison of U.S. Presidential Candidates During the 2008 Primary Election Campaign. Journal of Political Marketing, 11(3), 208-230. https:// doi.org/10.1080/15377857.2012.699424

Pemkab-Purbalingga. (2020). Tentang Purbalingga.

Pew. (2015). Mobile Messaging and Social Media 2015. In Pew Research Center.

Pramuk, J. (2016). Trump expected to name fast food CEO Andy Puzder as pick for Labor secretary. CNBC.

Rachmat, M. (2014). The Impact of Political Brand Trust on Voting Intention : Evidence from 2013 North Maluku Governor Election. The IUP Journal of Brand Management.

Rohmah, N. N. (2020). Media Sosial Sebagai Media Alternatif Manfaat dan Pemuas Kebutuhan Informasi Masa Pandemik Global Covid 19 (Kajian Analisis Teori Uses And Gratification). Al-I'lam: Jurnal Komunikasi Dan Penyiaran Islam, 1-16.

Rutter, R., Roper, S., \& Lettice, F. (2016). Social media interaction, the university brand and recruitment performance. Journal of Business Research, 69(8), 3096-3104. https:// doi.org/10.1016/j.jbusres.2016.01.025

Saboo, A. R., Kumar, V., \& Ramani, G. (2016). Evaluating the impact of social media activities on human brand sales. International Journal of Research in Marketing, 33(3), 524-541. https://doi. org/10.1016/j.ijresmar.2015.02.007
Saridakis, C., Baltas, G., Oghazi, P., \& Hultman, M. (2016). Motivation Recipes for Brand-Related Social Media Use: A Boolean-fsQCA Approach. Psychology and Marketing, 33(12), 1062-1070. https:// doi.org/10.1002/mar.20940

Schofield, P., \& Reeves, P. (2015). Does the factor theory of satisfaction explain political voting behaviour? European Journal of Marketing, 49(5/6), 968-992. https://doi.org/10.1108/EJM-08-2014-0524 Schweidel, D. A., \& Moe, W. W. (2014). Listening in on social media: A joint model of sentiment and venue format choice. Journal of Marketing Research, 51(4), 387-402. https:// doi.org/10.1509/jmr.12.0424

Sharifpour, Y. (2018). Effects of Electronic Word-of-Mouth on Consumers Purchase Intentions Through Brand Association in Iran Perspective. Management, 2, 1-12. https://doi.org/10.31058/j.mana.2018.21001 Sijoria, C., Mukherjee, S., \& Datta, B. (2018). Impact of the antecedents of eWOM on CBBE. In Marketing Intelligence and Planning. https://doi.org/10.1108/MIP-10-2017-0221

Susanto, E. H. (2017). MEDIA SOSIAL SEBAGAI PENDUKUNG JARINGAN KOMUNIKASI POLITIK. Jurnal ASPIKOM, 3(3), 379-398. https://doi. org/10.24329/aspikom.v3i3.123

Tinarbuko, S. (2019). Membaca Makna Iklan Politik Pilpres 2019. Mudra Jurnal Seni Budaya, 34(2), 250-258. https://doi. org/10.31091/mudra.v34i2.707

Van Steenburg, E., \& Guzmán, F. (2019). The influence of political candidate brands during the 2012 and 2016 US presidential elections. European Journal of Marketing, 53(12), 2629-2656. https://doi.org/10.1108/ EJM-06-2018-0399

Yuan, C. L., Kim, J., \& Kim, S. J. (2016). Parasocial relationship effects on customer equity in the social media context. Journal of Business Research, 69(9), 3795-3803. https:// doi.org/10.1016/j.jbusres.2015.12.071 